\title{
A construção narrativa de Barnabé como um modelo literário de generosidade à luz de Atos dos Apóstolos 4,32-5, 1
}

\author{
Orientador: Geraldo Dondici Vieira \\ Mestrando: Alessandra Serra Viegas \\ Área de Concentração: Teologia Bíblica \\ Linha de Pesquisa: Análise e Interpretação de Textos do Antigo e \\ Novo Testamento
}

À primeira vista, Barnabé se nos apresenta como um personagem aparentemente secundário na tessitura do livro de Atos dos Apóstolos, figurando no intercurso dos blocos narrativos dedicados a Pedro e a Paulo. No entanto, ao estudar mais profundamente as perícopes relativas a este homem bom, generoso e com grande capacidade de acolher ao próximo, depara-se com a sua importância para o desenvolvimento da trama narrativa do segundo livro da obra lucana. O presente trabalho propõe-se a analisar Atos 4,32-5,11 com o intuito de apresentar a construção narrativa do personagem Barnabé como um modelo literário de generosidade e bondade que possui uma mensagem comunicativa direcionada ao seu ouvinte-leitor. Ao mesmo tempo, aventa-se a possibilidade do autor de Atos dos Apóstolos utilizar, para a confecção da sua obra e deste personagem, elementos da literatura e da historiografia gregas desde Homero até o período helenístico, utilizando 'o modo de narrar grego’.

Palavras-chave: Barnabé; Literatura e Historiografia Gregas; Exegese; Análise Narrativa. 